\title{
Persistent low concentrations of diarrhetic shellfish toxins in green mussels Perna viridis from the Johor Strait, Singapore: first record of diarrhetic shellfish toxins from South-East Asia
}

\author{
Michael James Holmes ${ }^{1, *}$, Serena Lay Ming Teo ${ }^{1}$, Fu Chin Lee ${ }^{1}$, Hong Woo Khoo ${ }^{2}$ \\ 'Bioscience Centre and ${ }^{2}$ Department of Biological Sciences, National University of Singapore, 119260 Singapore
}

\begin{abstract}
Liquid chromatography-selected reaction monitoring mass spectrometry was used to identify and quantify Diarrhetic Shellfish Poisoning (DSP) toxins for the first time from tropical shellfish. Persistent, low concentrations of okadaic acid, 6 isomers of okadaic acid, and 5 isomers of dinophysistoxin-1 (DTX-1) were detected from green mussels Perna viridis from 3 sites in the Johor Strait, Singapore, between October 1995 and December 1997. Isomers of okadaic acid and DTX-1 generally occurred in higher concentrations than okadaic acid. The highest concentration of any single DSP toxin detected from Singapore shellfish was $97 \mathrm{ng} \mathrm{g}^{-1}$ mussel digestive tissue (wet weight) of an isomer of DTX-1 (DTX-1a). The maximum concentration of okadaic acid detected was $24 \mathrm{ng} \mathrm{g}^{-1}$ digestive tissue. These concentrations are well below the generally recommended limit for consumption of DSP toxins for humans $\left(\sim 1 \mu \mathrm{g}\right.$ toxin $\mathrm{g}^{-1}$ digestive tissue). Naturally contaminated mussels rapidly depurated okadaic acid when held in a laboratory aquarium, however, okadaic acid and some isomers of okadaic acid and DTX-1 could still be detected $\left(<1 \mathrm{ng} \mathrm{g}^{-1}\right)$ after $32 \mathrm{~d}$. Phytoplankton samples from the Johor Strait were examined for the origin of the DSP toxins found in green mussels. Four species of dinophysoid dinoflagellates were found, with Dinophysis caudata the most frequent and abundant species; although, cell densities did not exceed 5 cells $1^{-1}$ Five hundred $D$. caudata were micropipetted from phytoplankton samples and analysed for DSP toxins. Okadaic acid was detected $\left(7 \times 10^{-14} \mathrm{~g} \mathrm{cell}^{-1}\right)$ from $D$. caudata but no isomers of okadaic acid, DTX-1 or isomers of DTX-1. D. caudata were found in the gut contents of Singapore green mussels and probably contribute to the contamination of these shellfish; however, other as yet unidentified sources of DSP toxins may exist in the Johor Strait.
\end{abstract}

KEY WORDS: Diarrhetic Shellfish Poisoning . Okadaic acid - Dinophysistoxin - Perna viridis . Dinophysis caudata. Dinoflagellate . Mass spectrometry

\section{INTRODUCTION}

Diarrhetic Shellfish Poisoning (DSP) is a human seafood poisoning caused by eating shellfish contaminated with okadaic acid (Fig. 1) and structurally related toxins called dinophysistoxins (Yasumoto et al. 1978, 1985, Murata et al. 1982). Shellfish concentrate these toxins in their digestive tissues, with considerably reduced amounts accumulated in other tissues (Lee et al. 1987, Bauder et al. 1996). The toxins cause mainly gastrointestinal symptoms in humans with an

\footnotetext{
•E-mail: bschmj@nus.edu.sg
}

onset time between 0.5 to $12 \mathrm{~h}$ after ingestion of contaminated shellfish. The disease usually selfresolves within $3 \mathrm{~d}$ irrespective of medical treatment (Yasumoto et al. 1978). DSP was first documented in Japan and initial studies suggested that ingesting shellfish containing 12 'mouse units' of toxin(s) (equivalent to approx. $48 \mu$ g okadaic acid or $43 \mu$ g dinophysistoxin-1) was sufficient to cause mild poisoning in humans (Yasumoto et al. 1978, Lee et al. 1987). The safety limits for consumption of DSP toxins varies between countries, but generally when toxin levels exceed $200 \mathrm{ng}$ $\mathrm{g}^{-1}$ edible tissue the shellfish are considered unfit for human consumption (Quilliam \& Wright 1995). However, okadaic acid is a tumour-promoting agent (Fujiki 


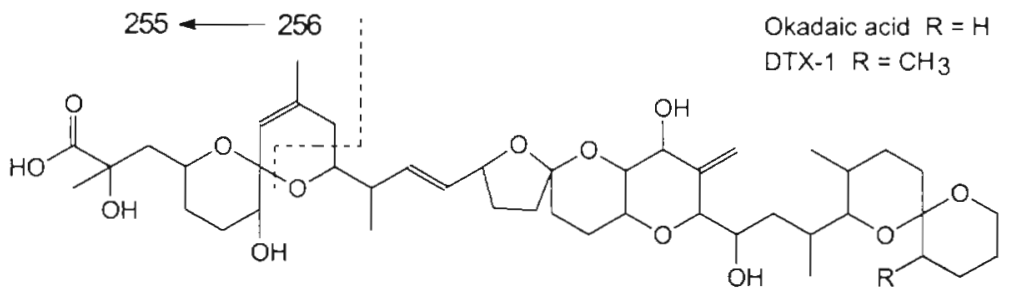

Fig. 1. Structure of okadaic acid and dinophysistoxin-1 (DTX-1). The origin of the $[\mathrm{M}-\mathrm{H}]^{-}$fragment ion $(\mathrm{m} / \mathrm{z} 255)$ used for detection of okadaic acid, DTX-1 and their isomers is indicated by the dashed line

et al. 1987) and Fessard (1998) recently suggested that the health risks of chronic exposure to DSP toxins may be underestimated because of the genotoxicity and tumour-promoting activity of okadaic acid.

Shellfish become contaminated with DSP toxins by filter feeding on dinoflagellates, especially certain species of Dinophysis (Yasumoto et al. 1980) and possibly the epibenthic Prorocentrum (Exuviaella) lima (Lawrence et al. 1998). A number of other Prorocentrum species also produce okadaic acid but their involvement in human intoxication has not been proven. Unambiguously determining the involvement of Dinophysis species in toxic events can be difficult because they cannot be cultured and wild populations are invariably mixed with other phytoplankton species (Subba Rao et al. 1993).

Okadaic acid was thought to be the native toxin synthesised by dinoflagellates but it is now believed to be derived from the hydrolysis of larger sulphated precursors such as dinophysistoxin-4 (DTX-4) (Hu et al. 1995a, Quilliam \& Ross 1996). Okadaic acid is released from these sulphated precursors by the action of esterases in the digestive tract of shellfish or by autolytic enzymes during the laboratory extraction of dinoflagellates (Quilliam \& Ross 1996). Many of the other analogues of okadaic acid reported from dinoflagellates and shellfish may also be derived from larger precursors. The structurally related compounds so far found in dinoflagellates and shellfish include: 3 isomers of okadaic acid called DTX-2, DTX-2b and DTX-2c (Hu et al. 1992, James et al. 1997a, Draisci et al. 1998); $35-$ methylokadaic acid also known as DTX-1 (Murata et al. 1982); 2- and 7-deoxy okadaic acid (Schmitz \& Yasumoto 1991); diol-esters of okadaic acid (Yasumoto et al. 1989, Hu et al. 1993); and 7-O-acylated derivatives of okadaic acid, DTX-1 and DTX-2 (Yasumoto et al. 1985, Marr et al. 1992). Acylation of okadaic acid derivatives is thought to occur in the digestive tract of shellfish since these modified toxins have not been detected from dinoflagellates (Yasumoto et al. 1989, Marr et al. 1992). Methyl esters of okadaic acid have also been reported from dinoflagellate extracts but are now thought to be created during the extraction of cells with methanol (Quilliam \& Ross 1996).

Many assays have been developed to detect DSP toxins. These include animal bioassays (Hamano et al.
1985), fluorescence HPLC (Lee et al. 1987), immunoassays (Levine et al. 1988), enzyme assays based upon the inhibition of PP1 or PP2A phosphatases (Holmes 1991) and liquid chromatography-mass spectrometry (LC-MS) (Pleasance et al. 1990). Each of these assays has advantages but LC-MS probably offers the greatest combination of sensitivity and selectivity for detecting known toxins. Generally, LC-MS detection of DSP toxins has been based upon selected ion monitoring of protonated ions generated by electrospray/ionspray ionisation (Pleasance et al. 1990. Marr et al. 1992, Draisci et al. 1995, Quilliam 1995, Quilliam \& Ross 1996, James et al. 1997a). The positive ions produced include salt adducts and fragments that lose up to 6 water molecules after collision induced dissociation. Recently, a modified LC-MS procedure called selected reaction monitoring (SRM) was used to monitor DSP toxins by their transition from positively charged parent ions to fragment ions produced by the loss of water (Poletti et al. 1996, James et al. 1997b, Draisci et al. 1998). Liquid chromatography-selected reaction monitoring mass spectrometry (LC-SRM MS) selects a parent ion, fragments this ion in a collision cell and then selects and detects a specific fragment ion(s). The detection and quantification of the compound of interest is based upon detection of fragment ions that can only be derived from the selected parent ion.

DSP has been reported mainly from temperate-cool regions, especially the waters of Europe and Japan although outbreaks have also occurred in eastern Canada, southern Australia, New Zealand, Chile (Hallegraeff 1995), the Gulf of California (Sierra-Beltrán et al. 1997) and Uruguay (Ferrari et al. 1997). To our knowledge, the only DSP-associated reports from the tropics were the detection of unspecified toxicity from bivalves from Karnataka State, India (Karunasagar et al. 1989a,b), and the mass mortality of fish in the Gulf of Thailand linked to dinoflagellate blooms of Dinophysis caudata (Hallegraeff 1995, Taylor et al. 1995). The unspecified toxicity of $D$. caudata (and $D$. miles) from South-East Asia was apparently confirmed from samples collected in the Philippines (Taylor et al. 1995). However, the DSP toxins contaminating tropical shellfish have not been previously identified. Singapore is an island nation in South-East Asia situated about $1^{\circ}$ north of the equator. We screened green mussels Perna 
viridis collected from northern Singapore for DSP toxins using LC-SRM MS and in this paper report the persistent low-level contamination of these shellfish with okadaic acid, isomers of okadaic acid and isomers of DTX-1.

\section{MATERIALS AND METHODS}

Monitoring of DSP phytoplankton in the eastern Johor Strait. Plankton samples from 2 sites in the eastern Johor Strait (Fig. 2) were monitored every 2 to $4 \mathrm{wk}$ from March 1997 to February 1998. Net samples from whole water columns were used to calculate cell densities of dinophysoid (Dinophysis spp. and Phalacroma spp.) dinoflagellates (Sidari et al. 1995). Plankton samples were collected at neap low tide using 2 vertical hauls of a $15 \mathrm{~cm}$ diameter, $10 \mu \mathrm{m}$ mesh plankton net. Each haul was from a depth of $10 \mathrm{~m}$ and nominally sampled a 177 l column of water (average water depth of Site 1 was $14 \mathrm{~m}$, Site 2 was $10 \mathrm{~m}$ ). The first vertical haul from each site was kept for inspection of living material and the second preserved with 1 to $5 \%$ formalin. Plankton samples were examined for dinoflagellates using an Olympus CK2 inverted microscope and the numbers of dinophysoid dinoflagellates counted. Dinoflagellates were identified based upon descriptions by Steidinger \& Tangen (1997).

Dinophysis caudata (Fig. 3) was the most common dinophysoid dinoflagellate in phytoplankton samples from the eastern Johor Strait. To determine if $D$. caudata was producing DSP toxins, 500 cells were individ-

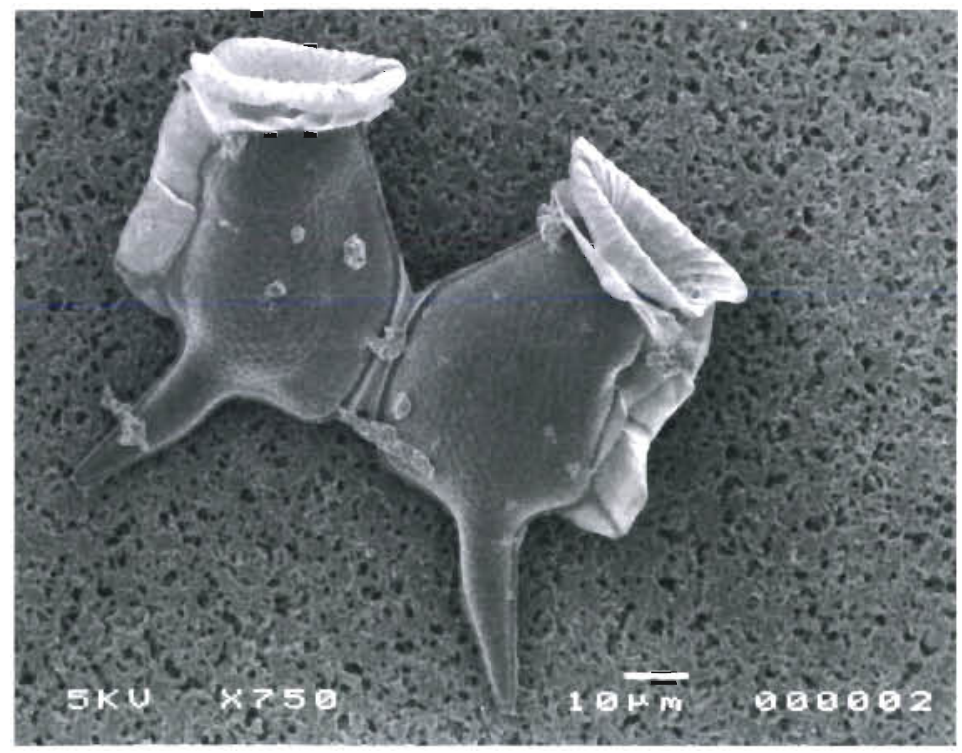

Fig. 3. Dinophysis caudata. Scanning electron micrograph of D. Caudata from the Johor Strait. Two recently divided cells are shown still connected by a megacytic bridge

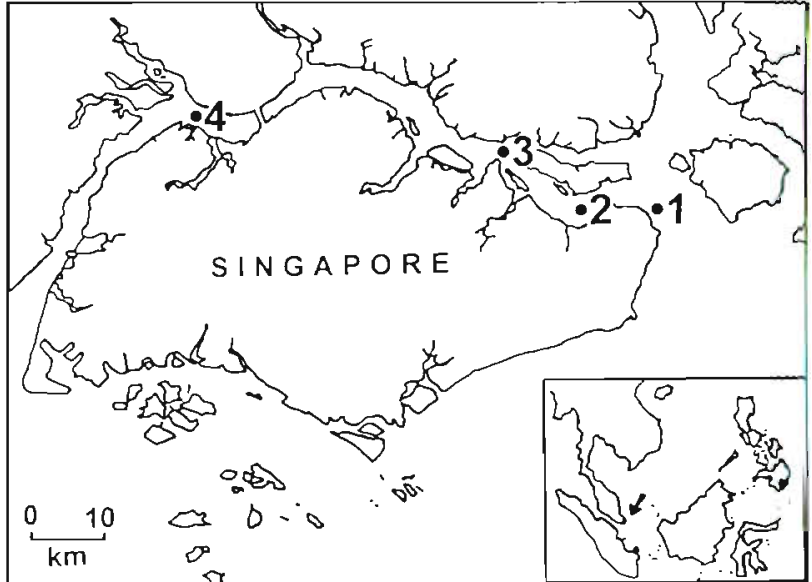

Fig. 2. Singapore and the Johor Strait. Sampling sites are indicated by numbers for phytoplankton (Sites 1,2) and green mussels at Changi (Site 2), Punggol (Site 3 ) and Sungei Buloh (Site 4)

ually micropipetted into a glass vial containing $1 \mathrm{ml}$ of methanol and the sample extracted and analysed for toxins using LC-SRM MS. The D. caudata were micropipetted from phytoplankton net samples collected from 4 sampling trips to Site 1 between April and June 1998. The cells were disrupted using an ultrasonic probe homogeniser (Misonix, NY) and the methanolseawater slurry dried under a stream of nitrogen, resuspended in $1 \mathrm{ml}$ of water and partitioned twice with $1 \mathrm{ml}$ of chloroform. The pooled chloroform fractions were dried under a stream of nitrogen and re-dissolved in $200 \mu$ l of $70 \%$ methanol.

Shellfish sampling and processing. Green mussels Perna viridis from 3 locations (Sites 2 to 4 ) along the northern shore of Singapore in the Strait of Johor (Fig. 2) were sampled between October 1995 and December 1997. Mussels from Changi (Site 2) were attached to a floating fish farm cage whereas mussels from Sungei Buloh (Site 4) were collected from an intertidal canal. Mussels from Punggol (nominally Site 3) were purchased from a local market. Where possible, similarly sized shellfish were selected.

Shellfish were washed with water to remove mud and debris. The digestive tissues were dissected free, pooled, weighed and homogenised using a Heidolph Diax 600 blender. Approximately $2 \mathrm{~g}$ (wet weight) of homogenised digestive tissue was extracted with $8 \mathrm{ml}$ of $80 \%$ methanol and partitioned with hexane and chloroform as described by Marr et al. (1994). The chloroform residue was dried under nitrogen, dissolved in $1 \mathrm{ml}$ of methanol and assayed for DSP toxins by LC. 
SRM MS. The extraction protocol was similar to the Dispersive Extraction protocol described in the accompanying documentation for the certified shellfish standard called MUS-2 (Marine Analytical Chemistry Standards Program, National Research Council, Halifax, Canada).

Liquid chromatography-selected reaction monitoring mass spectrometry (LC-SRM MS). Mass spectra were acquired on a Perkin Elmer Sciex API 300 turbo ionspray mass spectrometer using LC2Tune 1.3 or Sample Control 1.3 software. Spectra were analysed and integrated using BioMultiView 1.3. Negative parent ion and product ion spectra of okadaic acid and DTX-1 were acquired by infusion of standards in $70 \%$ methanol at $5 \mu \mathrm{min}^{-1}$ using a Harvard (Natick, MA) syringe infusion pump. Toxins were detected and quantifled in negative mode using LC-SRM MS. Samples were separated on a Luna C-18 (2) microbore column $(5 \times 0.1 \mathrm{~cm}, 5 \mu \mathrm{m})$ and eluted at $50 \mu \mathrm{min}^{-1}$ using a Shimadzu LC-10AD HPLC with a binary pump and $15 \mu$ gradient mixing chamber. A Perkin Elmer 200 autosampler was used to inject samples $(5 \mu \mathrm{l})$ into the HPLC. Two HPLC elution profiles were used, the first eluted compounds with $1: 1$ acetonitrile:water (containing $1 \mathrm{mM}$ ammonium acetate) for $4 \mathrm{~min}$ followed by a linear gradient to $95: 5$ acetonitrile:water ( $1 \mathrm{mM}$ ammonium acetatel at $4.5 \mathrm{~min}$ which was maintained for $15 \mathrm{~min}$. The second profile, which was used for most shellfish analyses, eluted samples for $4 \mathrm{~min}$ with 1:1 acetonitrile:water ( $1 \mathrm{mM}$ ammonium acetate) followed by a linear gradient to $100 \%$ isopropanol at $4.5 \mathrm{~min}$ which was maintained for $15 \mathrm{~min}$.

The mass spectrometer was used with turbo ionspray and orifice voltages of $-3900 \mathrm{~V}$ and $-48 \mathrm{~V}$, respectively, and turbo ionspray gas flowing at 61 $\mathrm{min}^{-1}$ at $350^{\circ} \mathrm{C}$. The collision energy was $65 \mathrm{~V}$ with nitrogen used for the collision gas as well as the nebulizer, curtain and turbo ionspray gases. Okadaic acid was detected by monitoring the transition of $\mathrm{m} / \mathrm{z}$ 803.3 to 255.2 and DTX-1 was detected by monitoring $\mathrm{m} / \mathrm{z} 817.3$ to 255.2. Blank injections (5 $\mu \mathrm{l}$ methanol) were run between samples. Okadaic acid or DTX-1 standards were run intermittently between samples to check the stability of the detector response. Unless otherwise indicated, $\mathrm{m} / \mathrm{z}$ are reported as truncated values (e.g. $\mathrm{m} / \mathrm{z} 805.5$ is reported as 805 ). M refers to the mass of the neutral non-salt molecule. Validation of the LC-SRM MS protocol for identifying and quantifying okadaic acid and DTX-1 from mussel tissue was by dispersive extraction of the certified mussel reference standard, MUS-2. LC-SRM MS detected $87 \pm 4 \%(n=3)$ of the certified okadaic acid and $106 \pm$ $8 \%(n=3)$ of the stated DTX-1 concentrations of the MUS-2 standard. The separation of okadaic acid and DTX-1 from less-polar isomers found in Singapore shellfish was confirmed by spike-recovery experi- ments after spiking mussel extracts with known concentrations of okadaic acid or DTX-1.

Depuration of DSP toxins from Singapore green mussels. Green mussels were collected from a Changi fish farm (Site 2) in May 1998 and held in a closed circulating seawater aquarium at the National University of Singapore to examine the depuration of low concentrations of naturally acquired DSP toxins. In a first experiment, mussels were held for $32 \mathrm{~d}$ in an aquarium with incoming seawater filtered to $20 \mu \mathrm{m}$ to remove phytoplankton. A second experiment held mussels for $27 \mathrm{~d}$ and used unfiltered seawater containing large numbers of pennate diatoms (but no dinophysoid or prorocentroid dinoflagellates) to provide some food for the shellfish. Samples of 4 to 9 mussels $(5$ to $12 \mathrm{~cm}$ shell height) were sacrificed every 2 to $4 \mathrm{~d}$ and the digestive tissues extracted for DSP toxins as described previously, except that the final extract for analysis was dissolved in $0.5 \mathrm{ml}$ of methanol. The wet weight of the digestive tissue of the mussels receiving filtered seawater declined from $19 \%$ of the edible tissue weight at the start of the experiment to $5 \%$ after $32 \mathrm{~d}$. Similarly, mussels held in unfiltered seawater declined from $14 \%$ at the start of the experiment to $8 \%$ after $27 \mathrm{~d}$, indicating that the pennate diatoms were nutritionally inadequate for green mussels. The seawater used for the experiments had a salinity of 30 to $32 \%, \mathrm{pH}$ of 7.8 to 8.1 and temperature of 28 to $30^{\circ} \mathrm{C}$.

Chemicals and solvents. Chemicals and extraction solvents were analytical reagent grade. Solvents for LC-MS were HPLC grade. $18 \mathrm{M} \Omega$ water was supplied from Milli-Q (Millipore) or Elga water purification systems. Certified toxin standards (OACS-1 and MUS-2) were purchased from the Marine Analytical Chemistry Standards Program, National Research Council, Halifax, Canada. DTX-1 was purchased from Calbiochem (San Diego, California).

Statistics. Unless otherwise indicated, values are expressed as means \pm 1 standard deviation with $n=$ sample size. Linear regressions were calculated using FigP (Biosoft, Cambridge) and coefficient of variations as per Sokal \& Rohlf (1981) with $p<0.05$ considered significant.

\section{RESULTS}

\section{LC-SRM MS of okadaic acid and DTX-1}

Negative mode, first quadrupole (Q1) scans of okadaic acid (OACS-1 standard) produced a single ion at $\mathrm{m} / \mathrm{z} 803$ corresponding to the $[\mathrm{M}-\mathrm{H}]^{-}$parent ion Product ion scans of this parent ion produced a fragmentation pattern dominated by an ion at $\mathrm{m} / \mathrm{z} 255$ (Fig. 4). We suggest that the origin of this fragment ion is from the carbonyl end of the parent molecule (Fig. 1) 


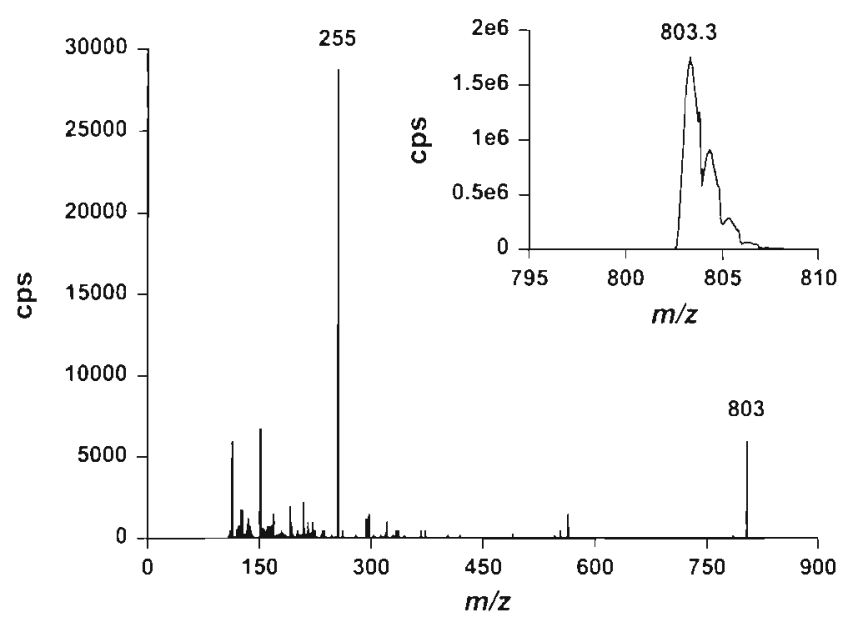

Fig. 4. Negative product ion scan (fragmentation) of okadaic acid showing the $m / z 255$ ion used for detection of okadaic acid and DTX-1 by LC-SRM MS. cps: counts per second. Inset shows negative ion (Q1) scan of the parent ion $[\mathrm{M}-\mathrm{H}]^{-}$of okadaic acid

with the same mass fragment detected in the product ion spectra of DTX-1 (data not shown). The $\mathrm{m} / \mathrm{z} 255$ fragment has the same mass as that of the major product ion of okadaic acid produced by negative fast atom bombardment mass spectrometry (Pleasance et al. 1990) and negative ionspray mass spectrometry of the newly discovered isomer of okadaic acid called DTX2c (Draisci et al. 1998). Infusion of toxin standards produced stable total ion currents for the SRM transition of okadaic acid from $\mathrm{m} / \mathrm{z} 803.3$ to 255.2 and DTX-1 $\mathrm{m} / \mathrm{z}$ 817.3 to 255.2 . The mass detection limit for okadaic acid was approximately $0.5 \mathrm{pg}$ on column with quantification and a linear response from 1 pg (Fig. 5, coeffi-

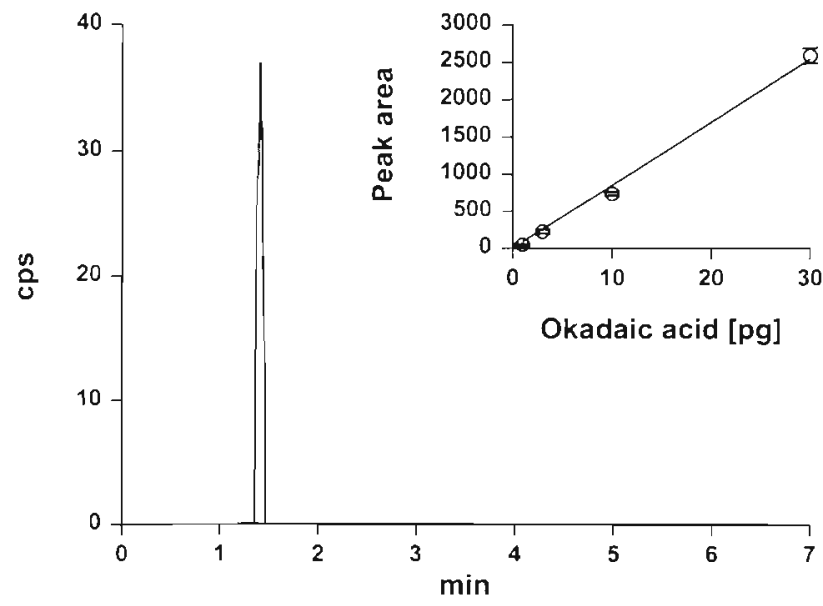

Fig. 5. LC-SRM MS ion chromatogram of $1 \mathrm{pg}$ of okadaic acid (from the OACS-1 standard). Inset shows partial calibration curve for okadaic acid $(p<0.001)$. The response was linear between $1 \mathrm{pg}$ and $1 \mathrm{ng}$. Values are means \pm 1 standard deviation, $\mathrm{n}=3$ cient of variation $=15 \%, \mathrm{n}=3$ ) to $1 \mathrm{ng}(\mathrm{p}<0.001)$. This level of detection compares favourably with the $40 \mathrm{pg}$ mass detection limit previously reported for selected ion monitoring of okadaic acid by Quilliam (1995) and 15 pg for LC-SRM MS by Draisci et al. (1998).

LC-SRM MS of the OACS-1 standard detected okadaic acid and a more-polar isomer of okadaic acid (Fig. 6). OACS-1 is known to contain low concentrations of an okadaic acid isomer (OACS-1 documentation). A small, early eluting peak was also observed for okadaic acid during LC-SRM MS of the DSP shellfish standard MUS-2 (data not shown). This small peak may be a more-polar isomer of okadaic acid or could have resulted from the collision-induced dissociation of higher molecular weight derivatives (such as DTX4 ) in the high-pressure expansion region before the first quadrupole. The MUS-2 standard contains okadaic acid and DTX-1 and was produced by the addition of Prorocentrum lima cells directly to mussel tissue (MUS-2 documentation). It is therefore likely that MUS-2 would also contain high molecular weight sulphated toxins such as DTX-4. DTX-4 is a sulphated high molecular weight analogue of okadaic acid ( $\mathrm{Hu}$ et al. 1995b) that elutes earlier than okadaic acid on a reverse-phase column and can fragment to produce $\mathrm{m} / \mathrm{z} 803$ ions (Quilliam \& Ross 1996). These $\mathrm{m} / \mathrm{z} 803$ fragment ions could then be detected by our LC-SRM MS method for okadaic acid.

The LC-SRM MS protocols eluted okadaic acid or DTX-1 isocratically within the first 2 min in 1:1 acetonitrile:water (Fig. 6). A column wash of either 95:5 acetonitrile:water or isopropanol was applied after 4 min to regenerate the column (because of the relatively large void volume between the gradient-mixer

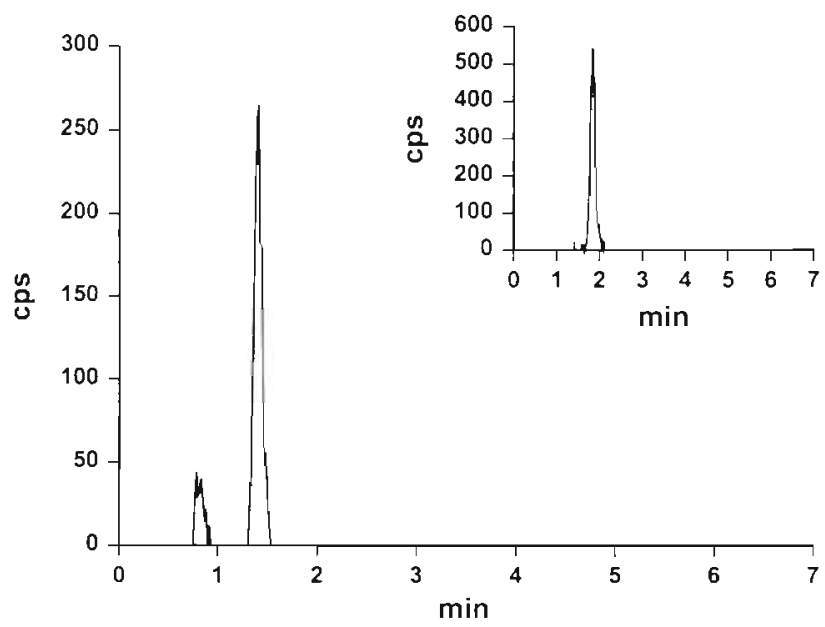

Fig. 6. LC-SRM MS ion chromatogram of $30 \mathrm{pg}$ of okadaic acid (OACS-1 standard) eluting at $1.4 \mathrm{~min}$ and a more-polar isomer eluting at $0.8 \mathrm{~min}$. Inset shows LC-SRM MS of DTX-1

from the mussel standard MUS-2 eluting at $1.9 \mathrm{~min}$ 
and autoinjector, the front of the solvent gradient reached the mass detector at about $8 \mathrm{~min}$ ). However, shellfish extracts contained low-polarity compounds that would bind okadaic acid to the reverse-phase column, resulting in an underestimation of toxin concentrations. After only 2 to 4 analyses of Singapore mussel extracts using the protocol with the $95: 5$ acetonitrile: water column wash, the intensity of the ion signal for okadaic acid (standard) would decrease compared to the same concentration injected before the shellfish samples. If the same concentration of okadaic acid was then repeatedly injected onto the column, the signal intensities gradually increased until the peaks returned to a similar size to those prior to the shellfish extracts (data not shown). This suggests that the reverse-phase column was retaining low-polarity compound(s) from the shellfish extracts that were also binding okadaic acid. Repeated injections of okadaic acid then appeared to saturate this secondary binding. The reduction in ion signal caused by shellfish extracts was not associated with changes in the retention time of okadaic acid. Replacing the column wash with isopropanol (the second elution protocol) resulted in reproducible ion intensities for okadaic acid standards measured before or after shellfish extracts. This indicates that okadaic acid-binding compounds from the shellfish extracts were being removed from the column using isopropanol but not $95 \%$ acetonitrile. Isopropanol was therefore used as the column wash for quantification of DSP toxins from Singapore shellfish samples.

\section{LC-SRM MS of Singapore shellfish for okadaic acid and its isomers}

Singapore green mussels collected from all 3 sites in the Johor Strait contained low concentrations of okadaic acid and up to 6 less-polar isomers of okadaic acid (Fig. 7, see Fig. 9a). The current convention is to name isomers of okadaic acid as DTX-2 with a lower case letter identifying the individual toxin (e.g. DTX-2, DTX-2b and DTX-2c). Until the 6 isomers in Singapore shellfish can be characterised we refer to them as DTX-2(1) to DTX-2(6) in order of their elution from the reverse-phase column. The number of isomers detected varied considerably between mussel samples. The most prominent of these toxins (frequency of occurrence and concentration) was DTX-2(2). (Quantification of the less-polar isomers assumes an equivalent molar response as okadaic acid.) Singapore shellfish often contained higher concentrations of DTX-2(2) than okadaic acid (Fig. 8). The other 5 isomers generally occurred in lower concentrations than okadaic acid and were only detected from a minority of
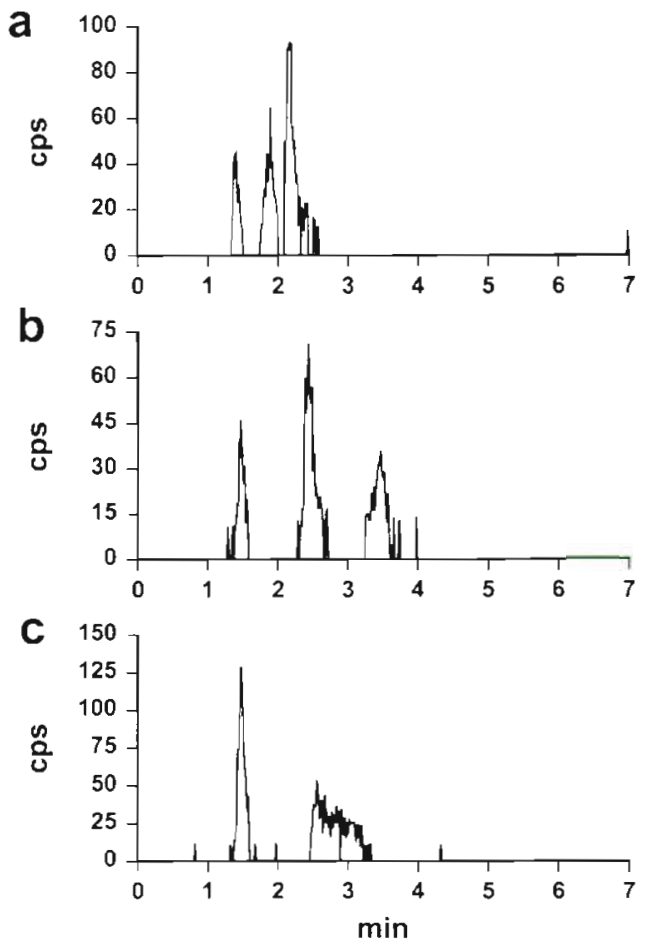

Fig. 7. LC-SRM MS ion chromatograms of Singapore green mussels analysed for okadaic acid. (a) Sungei Buloh (Site 4) mussel sample with okadaic acid (1.4 min) and 2 isomers, DTX-2(1) (1.9 min) and DTX-2(2) (2.2 min). (b) Punggol (Site 3) mussel sample with okadaic acid (1.5 min) and 2 isomers, DTX-2(2) (2.4 min) and DTX-2(5) (3.5 min). (c) Changi (Site 2) mussel sample with okadaic acid $(1.4 \mathrm{~min})$ and 2 isomers, DTX-2(2) (2.5 min) and DTX-2(3) (2.9 min)

shellfish samples. Unambiguously assigning the late eluting isomers (DTX-2[3] to DTX-2[6]) was difficult because of their generally low concentrations, overlapping elution times and their presence/absence in differing ratios. (An alternate hypothesis for the identity of the detected isomers is that they could be large, lowpolarity toxins that fragment to okadaic acid in the high-pressure expansion region before the first quadrupole. Singapore shellfish would then be contaminated with much greater concentrations of okadaic acid-related compounds than indicated in this paper because the initial fragmentation is unlikely to produce a $100 \%$ transition to okadaic acid.)

The maximum concentration of okadaic acid found in Singapore shellfish during the study period (1996-1997) was $15.1 \pm 1.1(\mathrm{n}=3) \mathrm{ng} \mathrm{g}^{-1}$ digestive tissue (wet weight) from a Punggol mussel sample (Fig. 8). A slightly higher concentration was subsequently detected from the Changi mussels used in the depuration experiment $\left(23.7 \pm 0.9 \mathrm{ng} \mathrm{g}^{-1}, \mathrm{n}=3\right)$. There was no apparent relationship between the concentrations of okadaic acid and the concentrations of DTX-2(2) (Fig. 8) or other isomers (data not shown). 

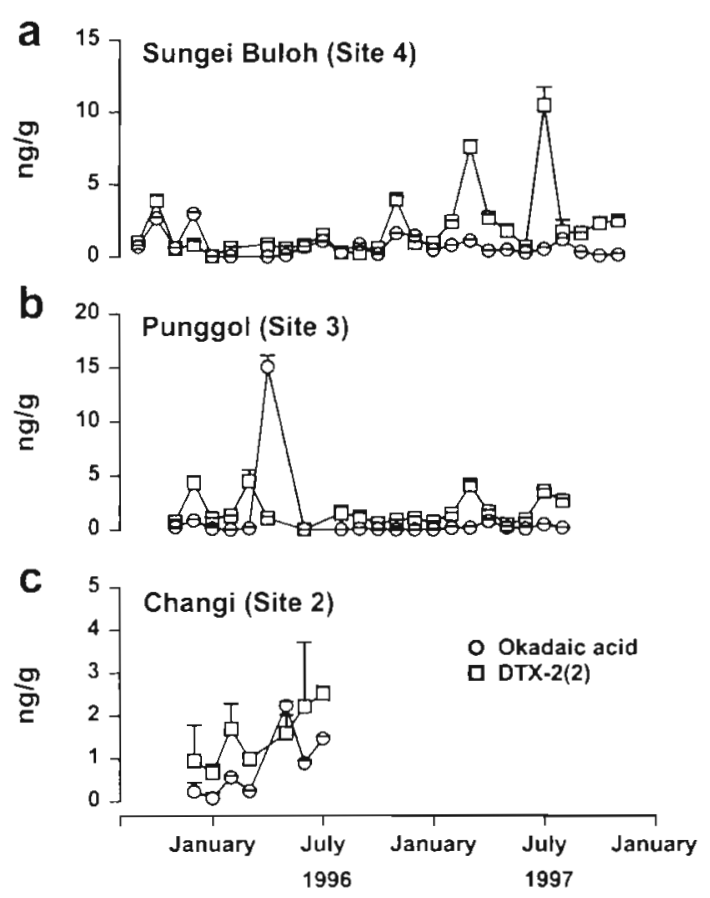

Fig. 8. Concentrations (ng $\mathrm{g}^{-1}$ wet wt digestive tissue) of okadaic acid (O) and DTX-2(2) (D) contaminating Singapore green mussels from (a) Sungei Buloh (Site 4), (b) Punggol (Site 3) and (c) Changi (Site 2). Values are means +1 standard deviation, $\mathrm{n}=3$

LC-SRM MS of Singapore shellfish samples (but not the MUS-2 mussel standard) eluted relatively large peaks at the gradient-front of the column wash $(8 \mathrm{~min}$ retention time, Fig. 9a). We have not determined the identity of these peaks but they may be acylated derivatives that are being detected by our LC-SRM MS method after they fragment in the high-pressure expansion region before the first quadrupole. Singapore shellfish samples analysed for DTX-1 also eluted similar peaks at the gradient-front of the column wash (Fig. 9b). MUS-2 does not contain significant concentrations of acylated derivatives such as DTX-3 (MUS-2 documentationj.

\section{LC-SRM MS of Singapore shellfish for DTX-1 and its isomers}

DTX-1 was only detected in trace amounts $<0.2 \mathrm{ng}$ $\mathrm{g}^{-1}$ digestive tissue) from a small number of Singapore mussel samples (data not shown). However, 5 lesspolar isomers of DTX-1 were detected (Figs. 9b \& 10). We have called these compounds DTX-1a to DTX-1e on the basis of their order of elution from the reversephase column. The particular combination of DTX-1 isomers detected from individual samples of Singapore shellfish varied considerably. However, DTX-1a and
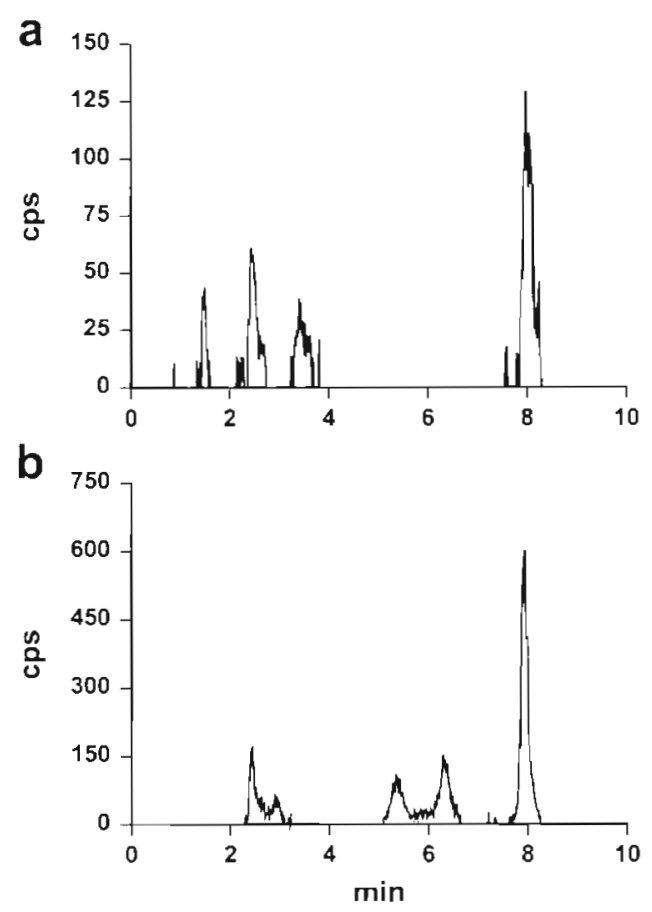

Fig. 9. LC-SRM MS ion chromatograms of Singapore green mussels from Punggol (Site 3). (a) Analysed for okadaic acid showing okadaic acid (1.5 min) and 2 isomers, DTX-2(2) (2.5 min) and DTX-2(4) (3.4 min). The large peak at the gradient front ( $8 \mathrm{~min}$ ) may be an acylated derivative(s) of okadaic acid. (b) Analysed for DTX-1 showing 4 isomers, DTX-1a (2.4 min), DTX-1b (2.9 min), DTX-1c (5.4 min) and DTX-1e (6.3 min). The large peak at the gradient front ( $8 \mathrm{~min}$ ) may be an acylated derivative(s) of DTX-1

DTX-1c were detected from most samples. Similar to the analysis for okadaic acid, unambiguously assigning the identity of the late eluting isomers (DTX-1c to DTX-1e) was difficult because of low concentrations, overlapping retention times and their presence/ absence in differing ratios. Generally, DTX-1a (and putatively DTX-1c) occurred in the highest concentrations with a maximum concentration of DTX-1a of 97.3 $\pm 8.8(\mathrm{n}=3) \mathrm{ng} \mathrm{g}^{-1}$ digestive tissue found in a sample of Punggol mussels collected in late 1996 (Site 3, Fig. 11). (Quantification of the DTX-1 isomers assumes an equivalent molar response to DTX-1.) There was no apparent relationship between the concentrations of DTX-1 isomers and the concentrations of okadaic acid or its isomers (compare Figs. 8 \& 11).

\section{Depuration of DSP toxins from green mussels in a laboratory aquarium}

The persistent, low concentrations of DSP toxins found in Singapore mussels suggest that the shellfish are exposed to a continuous low concentration 

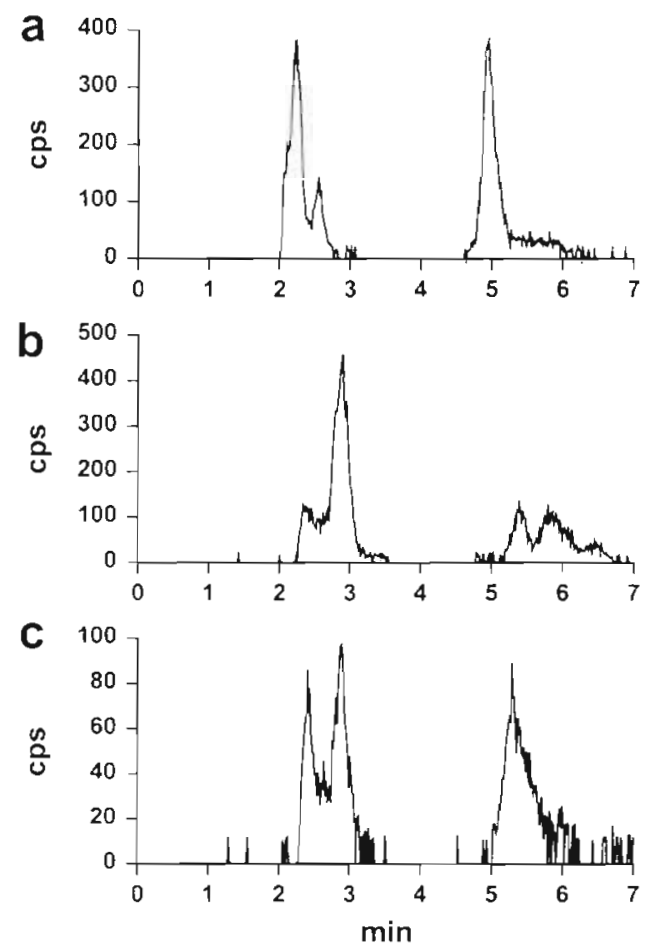

Fig. 10. LC-SRM MS ion chromatograms of Singapore green mussels analysed for DTX-1 (a) Sungei Buloh (Site 4) mussel sample with 3 isomers of DTX-1, DTX-1a eluting at 2.2 min, DTX-1b (2.6 min) and DTX-1c (5.0 min). (b) Punggol (Site 3) mussel sample with 4 isomers of DTX-1, DTX-1a (2.4 min), DTX-1b (2.9 min), DTX-1c (5.4 min) and DTX-1d $(5.9 \mathrm{~min})$. (c) Changi (Site 2) mussel sample with 3 isomers of DTX-1, DTX$1 \mathrm{a}(2.4 \mathrm{~min}), \mathrm{DTX}-1 \mathrm{~b}(2.8 \mathrm{~min})$ and DTX $-1 \mathrm{c}(5.4 \mathrm{~min})$

source(s) of these toxins and/or that the mussels retain low concentrations of toxins for extended periods of time. To determine if green mussels can retain low concentrations of DSP toxins we analysed Changi mussels held in an experimental aquarium over $32 \mathrm{~d}$. These mussels contained the highest contamination of okadaic acid detected during this study $(23.7 \pm 0.9 \mathrm{ng}$ $\mathrm{g}^{-1}$ digestive tissue, $\mathrm{n}=3$ ). After $11 \mathrm{~d}$, the okadaic acid concentration had dropped 10-fold to $2.2 \pm 0.1 \mathrm{ng} \mathrm{g}^{-1}$ ( $\mathrm{n}$ = 3) (Fig. 12). However, this initial rapid depuration was followed by a slower phase with persistent low concentrations $\left(<1 \mathrm{ng} \mathrm{g}^{-1}\right)$ of okadaic acid (and DTX1a) still detectable after $32 \mathrm{~d}$ (Fig. 12). The okadaic acid concentration dropped below the 'average' concentration for Singapore mussels $\left(0.8 \pm 2.1 \mathrm{ng} \mathrm{g}^{-1}, \mathrm{n}=159\right)$ within 11 to $15 \mathrm{~d}$ and reached $0.5 \pm 0.1 \mathrm{ng} \mathrm{g}^{-1}(\mathrm{n}=3)$ after $32 \mathrm{~d}$. Only low concentrations of other isomers were detected during the experiment; although some of these toxins were still detectable after $32 \mathrm{~d}$ depuration (Fig. 12). Low concentrations of DSP toxins were also detected after $27 \mathrm{~d}$ from mussels receiving unfiltered seawater containing pennate diatoms (data not shown).
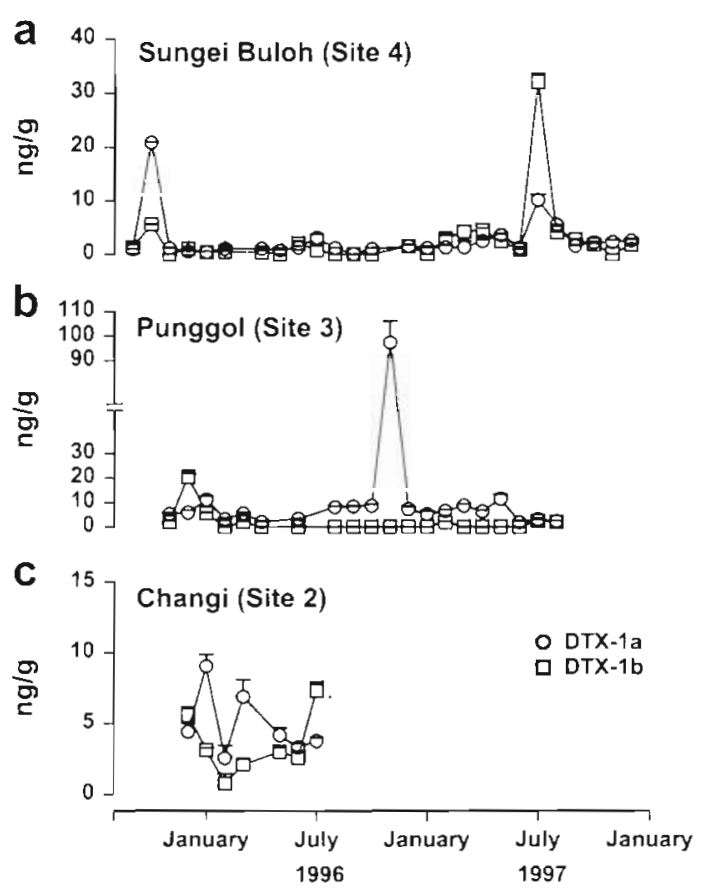

Fig. 11. Concentrations (ng g $\mathrm{g}^{-1}$ wet wt digestive tissue) of 2 isomers of DTX-1, DTX-1a (O) and DTX-1b (D), contaminating Singapore green mussels from (a) Sungei Buloh (Site 4), (b) Punggol (Site 3) and (c) Changi (Site 2). Values are means +1 standard deviation, $\mathrm{n}=3$
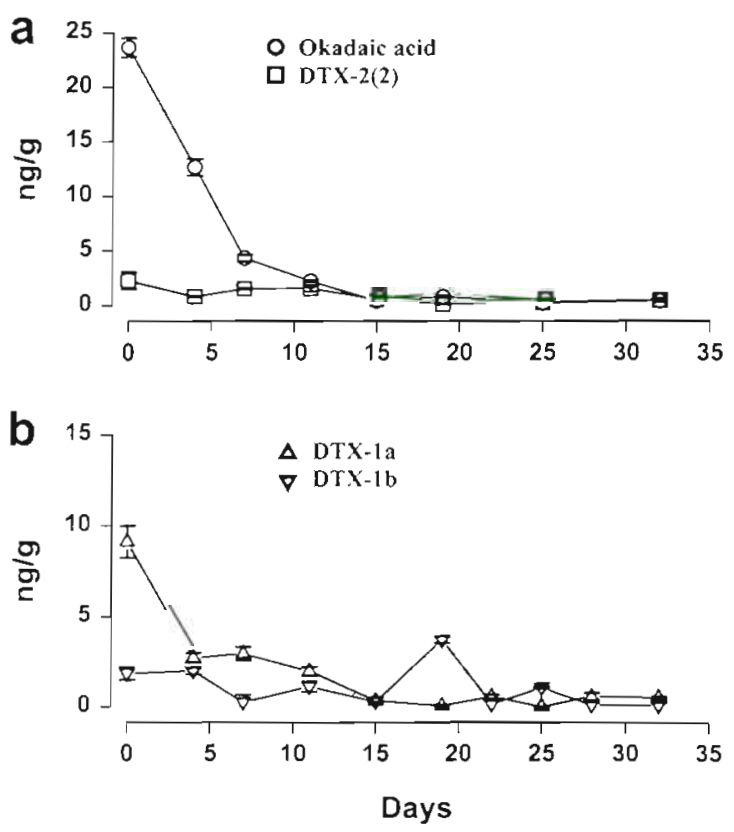

Fig. 12. Depuration of DSP toxins from green mussels collected from Site 2 (Changi) and held in experimental aquaria for $32 \mathrm{~d}$ without supplemental feeding. (a) Okadaic acid (O) and DTX-2(2) (a). (b) DTX-1a $(\Delta)$ and DTX-1b ( $\nabla)$. Values are means \pm 1 standard deviation, $\mathrm{n}=3$ 


\section{Origin of DSP toxins in shellfish from the Johor Strait}

The phytoplankton samples collected from the eastern Johor Strait (near the Changi mussel site) were generally dominated by chain-forming diatoms; although heterotrophic and photosynthetic dinoflagellates were also common at both sites. Blooms of non-chain-forming species of Gymnodinium spp. were occasionally observed and Prorocentrum cf. micans and Ceratium cf. furca were present in most samples. We observed 4 dinophysoid species from Singapore phytoplankton, with Dinophysis caudata usually the most common and abundant; although the maximum density for all dinophysoids was less than

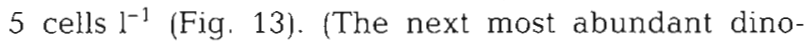
physoid was a species of Phalacroma.) However, LCSRM MS analysis of $500 \mathrm{D}$. caudata micropipetted from samples from the Johor Strait detected only 7.2 $\pm 3.8 \times 10^{-14} \mathrm{~g} \mathrm{cell}^{-1}(\mathrm{n}=4)$ of okadaic acid (data not shown). No DTX-1 or isomers of okadaic acid or DTX-1 could be detected.

Microscopic observations of the stomach contents of green mussels collected from Changi (Site 2) and Sungei Buloh (Site 4) revealed intact cells and empty hemivalves of Dinophysis caudata. Other dinoflagellates observed in the stomach contents included Prorocentrum cf micans and Protoperidinium spp.
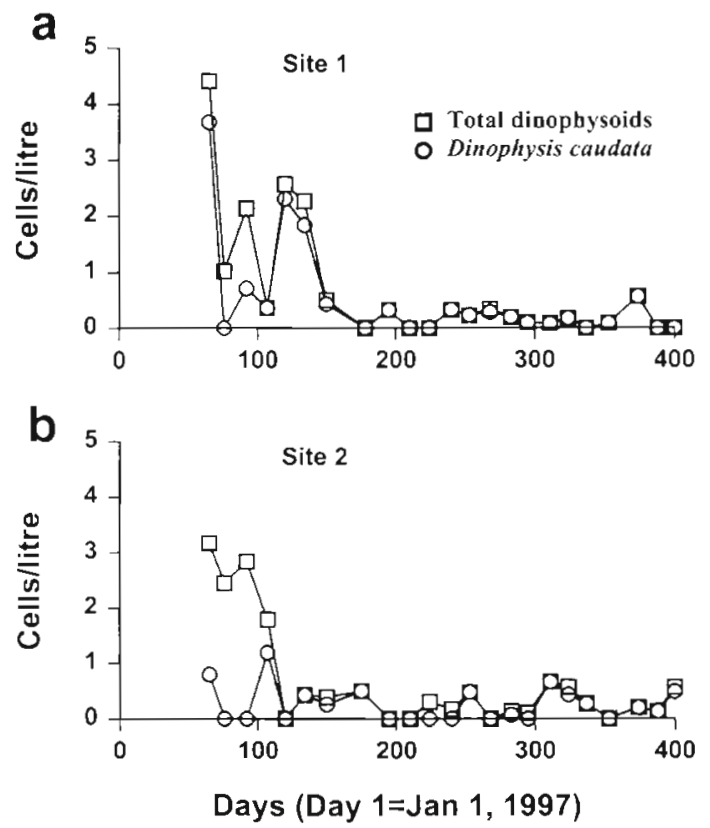

Fig. 13. Cell densities of total dinophysoid dinoflagellates ( $\square$ ) and Dinophysis caudata (O) from the Johor Strait for 1997 and early 1998. (a) Site 1 (b) Site 2 (Changi)

\section{DISCUSSION}

The sensitivity and selectivity of microbore HPLC combined with selected reaction mass spectrometry detection has allowed us to detect and quantify DSP toxins for the first time from tropical waters. Singapore green mussels were nearly always contaminated with low concentrations of okadaic acid, between 1 and 6 isomers of okadaic acid and 1 and 5 isomers of DTX-1. The relative toxicity of the isomers of okadaic acid and DTX-1 detected from Singapore mussels will need to be assessed before rational decisions can be made as to their threat to human health. However, in the absence of this data, a cautious approach assuming an equivalent potency to okadaic acid is appropriate. Because our LC-SRM MS methods rely upon detection of the carboxylic acid fragment of okadaic acid and DTX-1, all the isomers we have detected must be acidic toxins. Generally, the carboxylic acid group is required for the biological activity of DSP toxins (Nishiwaki et al. 1990). The detection of okadaic acid and numerous isomers of okadaic acid and DTX-1 from Singapore green mussels indicates the need for monitoring of tropical shellfish for DSP toxins. However, the highest okadaic acid concentration detected from Singapore mussels (24 ng $\mathrm{g}^{-1}$ digestive tissue) was 40 -fold lower than the maximum recommended level for human consumption (based upon the digestive tissue forming $20 \%$ of the weight of edible tissue and a limit of $200 \mathrm{ng}$ toxin $\mathrm{g}^{-1}$ edible tissue). The highest concentration of any DSP toxin detected from Singapore shellfish was $97 \mathrm{ng}$ of DTX-1 $\mathrm{a} \mathrm{g}^{-1}$, also well below the recommended safety limit.

The concentrations of isomers of okadaic acid from Singapore mussels were often higher than the concentration of okadaic acid. Unfortunately, the only 3 isomers of okadaic acid that have been characterised to date, DTX-2, DTX-2b and DTX-2c, are not commercially available so we could not determine if any of the Singapore toxins correspond to these isomers. All of the isomers detected from Singapore shellfish as well as DTX-2, DTX-2b and DTX-2c are less-polar than okadaic acid. Prior to this study, isomers of okadaic acid and DTX-1 had been detected only from European shellfish and phytoplankton. DTX-2 and DTX-2b were first detected from Irish mussels ( $\mathrm{Hu}$ et al. 1992, James et al. 1997a) and DTX-2c was recently identified from Irish strains of Dinophysis acuta (Draisci et al. 1998). Unnamed isomers of okadaic acid and DTX-1 have also been reported from Italian mussels (Draisci et al. 1995).

Four species of dinophysoid dinoflagellate were observed in the eastern Johor Strait, with Dinophysis caudata being the most common and abundant. Okadaic acid but not DTX-1 was detected from this 
species. To our knowledge this is the first report identifying the toxin produced by $D$. caudata. However, the concentration of okadaic acid in Singapore $D$. caudata $\left(7 \times 10^{-14} \mathrm{~g} \mathrm{cell}^{-1}\right)$ was low, being almost 1000 -fold lower than that found in $D$. acuta from Ireland (James et al. 1997b). D. caudata likely contributes to the accumulation of okadaic acid in Singapore shellfish since we observed both intact cells and empty valves of this species in the gut contents of green mussels. Mussels have been suggested to be capable of preferential selection of dinophysoid dinoflagellates (Sidari et al. 1998). However, the low cell concentration of okadaic acid in $D$. caudata and the low density of this species in Singapore phytoplankton $\left(<5\right.$ cells $\left.~^{-1}\right)$ suggest that there may be other sources of toxin(s). An 'average' green mussel ( $2 \mathrm{~g}$ digestive tissue) would have to filter more than $135000 \mathrm{l}$ of seawater containing $5 \mathrm{D}$. caudata ${ }^{-1}$ to accumulate the maximum okadaic acid concentration of $24 \mathrm{ng}$ okadaic acid $\mathrm{g}^{-1}$ digestive tissue found in this study (ignoring simultaneous toxin depuration). Alternatively, $D$. caudata may show large temporal variations in cell toxicity as has been suggested for other species of Dinophysis (Masselin et al. 1992, Subba Rao et al. 1993, Suzuki et al. 1997)

The origin of the isomers of DTX-1 contaminating Singapore shellfish is not known. Shellfish are believed to be able to modify DSP toxins by acylation of the $7-\mathrm{OH}$ of okadaic acid, DTX-1 or DTX-2 (Yasumoto et al. 1989, Marr et al. 1992). The isomeric transformation of DSP toxins by shellfish has not been reported; although epimerisation of ciguatoxins (also large lipidsoluble, polyether toxins) can occur in fishes (Lewis \& Holmes 1993). We assume that the isomers of the toxins found in Singapore mussels originate from dinophysoid dinoflagellates but this remains to be determined. The origin of only 2 okadaic acid isomers (DTX-2 and DTX-2c) is known. DTX-2 originates from Dinophysis acuta and is the predominant DSP toxin contaminating Irish mussels (Carmody et al. 1996, James et al. 1997b). DTX-2c also originates from $D$. acuta but has yet to be reported from shellfish (Draisci et al. 1998).

Low concentrations of DSP toxins can persist for weeks in the digestive tissue of green mussels. The 'average' concentrations of DSP toxins found in Singapore green mussels over the study period $\left(<1 \mathrm{ng} \mathrm{g}^{-1}\right.$ digestive tissue) can be explained by the retention of these toxins in the digestive tissue of mussels after episodic infusions of toxins rather than from a continuous infusion from the plankton. The depuration of DSP toxins from Singapore green mussels was qualitatively similar to temperate species (Mytilus edulis and $M$. galloprovincialis) which also show a slower second phase or exponential decay of DSP toxin depuration (Yasumoto et al. 1978, Poletti et al. 1996). However, the initial rate of depuration of okadaic acid from naturally contaminated Singapore green mussels in this study was much slower than that found by Fong et al. (1997) for 10-fold higher initial concentrations of okadaic acid. The rapid depuration of high concentrations of DSP toxins from green mussels may be a mechanism that reduces human exposure in South-East Asia to concentrations of DSP toxins that cause gastrointestinal illness. It remains to be determined if there are any effects on humans (or marine organisms) caused by chronic exposure to persistent low toxin concentrations such as those found in this study.

Acknowledgements. We thank Kenneth Low, Tay Hui Cheng, Radha Dayanidhi, Ng Si Mei, Wahida Bte Esa and Victor Khoo Hock Soon for assistance with sample collection and processing, and Loy Gek Luan for help with SEM and Yip Hoi Kee for photography. We thank Subodth Nimkar for assistance with mass spectrometry and PE Biosystems for loan of an autosampler. This work was carried out in collaboration with the Centre for Remote Imaging, Sensing and Processing. We thank the management of the Sungei Buloh Nature Reserve for access to mussels on the intertidal shore of the Reserve. This work was funded by NUS grant RP 960334 .

\section{LITERATURE CITED}

Bauder AG, Cembella AD, Quilliam MA (1996) Dynamics of the diarrhetic shellfish toxins from the dinoflagellate, Prorocentrum lima, in the bay scallop, Argopecten irradians. In: Yasumoto T, Oshima Y, Fukuyo Y (eds) Harmful and toxic algal blooms. Intergov Oceanogr Comm UNESCO, Sendai, $p$ 433-436

Carmody EP, James KJ, Kelly SS (1996) Dinophysistoxin-2: the predominant diarrhoetic shellfish toxin in Ireland. Toxicon 34:351-359

Draisci R, Lucentini L, Giannetti L, Bori P, Stacchini A, (1995) Detection of diarrhoetic shellfish toxins in mussels from Italy by liquid chromatography-mass spectrometry. Toxicon 33:1591-1603

Draisci R, Giannetti L, Lucentini L, Marchiafava C, James KJ, Bishop AG, Healy BM, Kelly SS (1998) Isolation of a new okadaic acid analogue from phytoplankton implicated in diarrhetic shellfish poisoning. J Chromatogr A 798:137-145

Ferrari G, Méndez SM, Brazeiro A (1997) Dinophysis acuminata associated with diarrhetic shellfish poisoning in Uruguay. VIII Int Conf Harmful Algae, Vigo (25-29 June 1.997) Abstracts, p 73

Fessard V (1998) Okadaic acid and carcinogenesis. In: Wyatt $\mathrm{T}$ (ed) Harmful algae news, Vol 17. International Oceanographic Commission of UNESCO, p 10-11

Fong LLI, Chua YSV, Lee FC, Holmes MJ, Wong V, Khoo HW (1997) Uptake and depuration of diarrhetic shellfish toxin in the green mussel, Perna viridis (Linnaeus, 1758) fed with the dinoflagellate, Prorocentrum lima (Ehrenberg) Dodge. In: Vigers $G$, Ong KS, McPherson C, Millson N Watson I, Tang A (eds) ASEAN marine environmental management: quality criteria and monitoring for aquatic life and human health protection. Proc ASEAN-Canada Tech Conf Mar Sci (24-28 June 1996), Penang, Malaysia. EVS Environmental Consultants, North Vancouver and Department of Fisheries Malaysia, IX p 6-18 
Fujiki H, Suganuma M, Suguri $H$, Yoshizawa S, Ojika $M$, Wakamatsu K, Yamada K, Sugimura T (1987) Induction of orthinine decarboxylase activity in mouse skin by a possible tumour promoter, okadaic acid. Proc Jpn Acad Ser B 63:51-53

Hallegraeff GM (1995) Harmful algae blooms: a global overview. In: Hallegraeff GM, Anderson DM, Cembella $A D$ (eds) Manual on harmful marine microalgae. International Oceanographic Commission Manuals and Guides 33, UNESCO, Paris, $\mathrm{p}$ 1-22

Hamano Y, Kinoshita Y, Yasumoto T (1985) Suckling mice assay for diarrhetic shellfish toxins. In: Anderson DM, White AW, Baden DG (eds) Toxic dinoflagellates. Elsevier, Amsterdam, p 383-388

Holmes CFB (1991) Liquid chromatography-linked protein phosphatase bioassay; a highly sensitive marine bioscreen for okadaic acid and related diarrhetic shellfish toxins. Toxicon 29:469-477

Hu T, Doyle J, Jackson D, Marr J, Nixon E, Pleasance S, Quilliam MA, Walter JA, Wright JLC (1992) Isolation of a new diarrhetic shellfish poison from Irish mussels. J Chem Soc Chem Commun 30:39-41

Hu T, deFreitas ASW, Doyle J, Jackson D, Marr J, Nixon E, Pleasance S, Quilliam MA, Walter JA, Wright JLC (1993) New DSP toxin derivatives isolated from toxic mussels and the dinoflagellates Prorocentrum lima and Prorocentrum concavum. In: Smayda TJ, Shimizu Y (eds) Toxic phytoplankton blooms in the sea. Elsevier, Amsterdam, p $507-512$

Hu T, Curtis JM, Walter JA, McLachlan JL, Wright JLC (1995a) Two new water-soluble DSP toxin derivatives from the dinoflagellate Prorocentrum maculosum: possible storage and excretion products. Tetrahedron Lett 36 : 9273-9276

Hu I, Curtis JM, Walter JA, Wright JLC (1995b) Identification of DTX-4, a new water-soluble phosphatase inhibitor from the toxic dinoflagellate Prorocentrum lima. J Chem Soc Chem Commun 597-599

James KJ, Carmody EP, Gillman M, Kelly SS, Draisci R, Lucentini L, Giannetti L (1997a) Identification of a new diarrhoetic toxin in shellfish using liquid chromatography with fluorimetric and mass spectrometric detection. Toxicon 35:973-978

James KJ, Bishop AG, Gillman M, Kelly SS, Roden C, Draisci R, Lucentini L, Giannetti L, Boria P (1997b) Liquid chromatography with fluorimetric, mass spectrometric and tandem mass spectrometric detection for the investigation of the seafood-toxin producing phytoplankton, Dinophysis acuta. J Chromatogr A 777:213-221

Karunasagar I, Segar K, Karunasagar I (1989a) Incidence of PSP and DSP in shellfish along the coast of Karnataka State (India). In: Okaichi T, Anderson DM, Nemoto T (eds) Red tides: biology, environmental science and toxicology. Elsevier, Amsterdam, p 61-64

Karunasagar I, Segar K, Karunasagar I (1989b) Potentially toxic dinoflagellates in shellfish harvesting areas along the coast of Karnataka State (India). In: Okaichi T, Anderson DM, Nemoto T (eds) Red tides: biology, environmental science and toxicology. Elsevier, Amsterdam, p 65-68

Lawrence J, Bauder A, Quilliam MA, Cembella AD (1998) Prorocentrum lima: a putative link to diarrhetic shellfish poisoning in Nova Scotia, Canada. In: Reguera B, Blanco $J$, Fernandez ML, Wyatt T (eds) Harmful algae. Xunta de Galicia and International Oceanographic Commission of UNESCO, Santiago de Compostela, p 78-79

Lee JS, Yanagai T, Kenma R, Yasumoto T (1987) Fluorometric determination of diarrhetic shellfish toxins by high-perfor- mance liquid chromatography. Agric Biol Chem 51 $877-881$

Levine L, Fujiki $H$, Yamada K, Ojika M, Gijka HB, Van Vunakis $H$ (1988) Production of antibodies and development of a radioimmunoassay for okadaic acid. Toxicon 26:1123-1128

Lewis RJ, Holmes MJ (1993) Origin and transfer of toxins involved in ciguatera. J Comp Biochem Physiol 106C: $615-628$

Marr JC, Hu T, Pleasance S, Quilliam MA, Wright JLC (1992) Detection of new 7-O-acyl derivatives of diarrhetic shellfish poisoning toxins by liquid chromatography-mass spectrometry. Toxicon 30:1621-1630

Marr JC, McDowell LM, Quilliam MA (1994) lnvestigation of derivatization reagents for the analysis of diarrhetic shellfish poisoning toxins by liquid chromatography with fluorescence detection. Nat Toxins 2:302-311

Masselin P, Lassus P, Bardouil M (1992) High performance liquid chromatography analysis of diarrhetic shellfish toxins in Dinophysis spp. from the French coast. J Appl Phycol 4:385-389

Murata $M$, Shimatani $M$, Sugitani $H$, Oshima Y, Yasumoto $T$ (1982) Isolation and structural elucidation of the causative toxin of the diarrhetic shellfish poisoning. Bull Jpn Soc Sci Fish 48:549-552

Nishiwaki S, Fujiki H, Suganuma M, Furuya-Suguri $H$, Matsushima $R$, Iida $Y$, Ojika $M$, Yamada $K$, Uemura $D$, Yasumoto T, Schmitz FJ, Sugimura T (1990) Structureactivity relationship within a series of okadaic acid derivatives. Carcinogenesis 11:1837-1841

Pleasance S, Quilliam MA, de Freitas ASW, Marr JC, Cembella AD (1990) Ion-spray mass spectrometry of marine toxins II. Analysis of diarrhetic shellfish toxins in plankton by liquid chromatography/mass spectrometry. Rapid Commun Mass Spectrom 4:206-213

Pleasance S, Quilliam MA, Marr JC (1992) Ionspray mass spectrometry of marine toxins, $\Gamma$. Determination of diarrhetic shellfish poisoning toxins in mussel tissue by liquid chromatography/mass spectrometry. Rapid Commun Mass Spectrom 6:121-127

Poletti R, Viviani R, Casadej C, Lucentini L, Giannetti L, Funari E, Draisci R (1996) Decontamination dynamics of mussels naturally contaminated with diarrhetic shellfish toxins relocated to a basin of the Adriatic Sea. In: Yasumoto T, Oshima Y, Fukuyo Y (eds) Harmful and toxic algal blooms. Intergovernmental Oceanographic Commission of UNESCO, Sendai, p 429-432

Quilliam MA (1995) Analysis of diarrhetic shellfish poisoning toxins in shellfish tissue by liquid chromatography with fluorometric and mass spectrometric detection. J AOAC 78:555-570

Quilliam MA, Ross NW (1996) Analysis of diarrhetic shellfish poisoning toxins and metabolites in plankton and shellfish by ion-spray liquid chromatography-mass spectrometry. In: Snyder PA (ed) Biochemical and biotechnological applications of electrospray ionization mass spectrometry American Chemical Society Symposium Series 619, Washington, DC, p 351-364

Quilliam MA, Wright JLC (1995) Methods for diarrhetic shellfish poisons. In: Hallegraeff GM, Anderson DM, Cembella $\mathrm{AD}$ (eds) Manual on harmful marine microalgae. International Oceanographic Commission Manuals and Guides 33. UNESCO, Paris, p 95-111

Schmitz FJ, Yasumoto I (1991) The 1990 United States-Japan seminar on bioorganic marine chemistry, meeting report. J Nat Prod 54:1469-1490

Sidari L, Nichetto P, Cok S, Sosa S, Tubaro A, Honsell G, Della 
Loggia R (1995) Phytoplankton detection and DSP toxicity: methodological considerations. J Appl Phycol 7:163-166

Sidari L, Nichetto P, Cok S, Sosa S, Tubaro A, Honsell G, Della Loggia R (1998) Phytoplankton selection by mussels, and diarrhetic shellfish poisoning. Mar Biol 131:103-111

Sierra-Beltrán AP, Green-Yee A, Ochoa JL (1997) First documented report of diarrhetic shellfish poisons (DSP) in shellfish from the Gulf of California, Mexico. In: VIII International Conference on Harmful Algae, Vigo (25-29 June 1997). Abstracts, p 184

Sokal RR, Rohlf FJ (1981) Biometry. WH Freeman and Company, San Francisco

Steidinger KA, Tangen K (1997) Dinoflagellates. In: Tomas $C R$ (ed) Identifying marine phytoplankton. Academic Press, San Diego, p 387-584

Subba Rao DV, Pan Y, Zitko V, Bugden G, Mackeigan $K$ (1993) Diarrhetic shellfish poisoning (DSP) associated with a subsurface bloom of Dinophysis norvegica in Bedford Basin, eastern Canada. Mar Ecol Prog Ser 97: $117-126$

Suzuki T, Mitsuya T, Imai M, Yamasaki M (1997) DSP toxin

Editorial responsibility: Otto Kinne (Editor),

Oldendorf/Luhe, Germany contents in Dinophysis forti and scallops collected at Mutsu Bay, Japan. J Appl Phycol 8:509-515

Taylor FJR, Fukuyo Y, Larsen J (1995) Taxonomy of harmful dinoflagellates. In: Hallegraeff GM, Anderson DM, Cembella A.D (eds) Manual on harmful marine microalgae. International Oceanographic Commission Manuals and Guides 33, UNESCO, Paris, p 283-317

Yasumoto T, Oshima Y, Yamaguchi M (1978) Occurrence of a new type of shellfish poisoning in the Tohoku district. Bull Jpn Soc Sci Fish 44:1249-1255

Yasumoto $T$, Oshima $Y$, Sugawara $W$, Fukuyo $Y$, Oguri $H$, Igarashi T, Fujita N (1980) Identification of Dinophysis fortii as the causative organism of diarrhetic shellfish poisoning. Bull Jpn Soc Sci Fish 46:1405-1411

Yasumoto T, Murata M, Oshima Y, Sano M, Matsumoto GK, Clardy J (1985) Diarrhetic shellfish toxins. Tetrahedron 41: 1019-1025

Yasumoto T, Murata M, Lee JS, Torigoe K (1989) Polyether toxins produced by dinoflagellates. In: Natori S, Hashiomoto K. Ueno U (eds) Mycotoxins and phycotoxins ' 88 . Elsevier, Amsterdam, p 375-382

Submitted: September 28, 1998; Accepted: December 23, 1998 Proofs received from author(s): April 29, 1999 